\title{
Glutensiz Ürünlerde Kullanılan Alternatif Protein Kaynakları
}

\author{
Sevgi Deren Yağd ${ }^{1 *}$, Zehra Gülsünoğlu Konuşkan ${ }^{2}$ \\ ${ }^{1 * I ̇}$ istanbul Aydın Üniversitesi, Sağlık Bilimleri Fakültesi, Beslenme ve Diyetetik Bölümü, İstanbul, Türkiye, (ORCID: 0000-0002-9519-5538) \\ sevgiyagdi@stu.aydin.edu.tr \\ ${ }^{2}$ İstanbul Aydın Üniversitesi, Sağlık Bilimleri Fakültesi, Beslenme ve Diyetetik Bölümü, İstanbul, Türkiye, (ORCID: 0000-0001-6497-1912) \\ zehragulsunoglu@aydin.edu.tr
}

(International Conference on Design, Research and Development (RDCONF) 2021 - 15-18 December 2021)

(DOI: 10.31590/ejosat.1045522)

\begin{abstract}
ATIF/REFERENCE: Yağdı, S. D., Gülsünoğlu Konuşkan, Z. (2021). Glutensiz Ürünlerde Kullanılan Alternatif Protein Kaynakları. Avrupa Bilim ve Teknoloji Dergisi, (32), 32-39.

$\ddot{O} \mathbf{z}$

Çölyak hastalığı kronik bir bağırsak hastalığı olup, gluten tüketilmesi sonucu semptomlar ortaya çıkmaktadır. Çölyak hastalığının en etkili tedavi yöntemi glutenin diyetten çıkarılmasıdır. Çölyak hastalarında görülen emilim bozuklukları ve makro-mikro besin ögesi eksiklikleri göz önünde bulundurulduğunda piyasadaki ürünlerin besin içeriklerinin zenginleştirilmesi kişinin hayat kalitesinin yükselmesine katkıda bulunur. Ayrıca, gluten firıncılık ürünlerinde önemli bir yere sahiptir ve glutenin çıkarılması ile aynı özelliklere sahip ürün üretmek oldukça zordur. Bu sebeple, glutensiz ürünlerin hem teknolojik özelliklerinin iyileştirilmesi hem de besleyici değerinin arttırılması önem kazanmaktadır. Glutene alternatif olarak kullanılan protein kaynakları, istenilen hamur yapısının oluşmasında, pişme sonrası renk, görünüş, tekstür ve lezzet gibi kalite özelliklerinin iyileştirilmesinde önemli bir rol oynar. Glutensiz ürünlerle yapılan çalışmalarda viskoelastiklik, besin içeriği, hamur sıkılığı, renk-tat-koku kabul edilebilirliği konularında çok fazla çalışma yapılmıştır. En çok kullanılan alternatif kaynaklar ise süt proteinleri, yumurta albümini ve bitkisel proteinlerdir. Ancak son yıllarda yüksek protein içeriklerinin yanı sıra yüksek miktarda biyoaktif madde içeren algler ve yenilebilir böcekler de glutene alternatif olarak kullanılmaya başlanmıştır. Bu derlemede glutensiz ürün üretiminde kullanılabilecek alternatif protein kaynakları ve bunların glutensiz ürünlerin besin içeriklerine ve teknolojik özelliklerine sağladığı katkılar ile ilgili bilgi verilmesi amaçlanmıştır.
\end{abstract}

Anahtar Kelimeler: Çölyak hastalığı, Protein ikamesi, Glutensiz fırıncılık ürünleri

\section{Alternative Protein Sources Used In Gluten-Free Products}

\begin{abstract}
Celiac disease is a chronic intestinal disease which occur as a result of gluten consuming. The most effective treatment for celiac disease is the elimination of gluten from the diet. Considering the malabsorption and macro-micro nutrient deficiencies, enrichment of nutrient composition in the gluten-free products can significantly increase the life quality of celiac patients. Moreover, gluten is main structureforming protein in dough and it is very difficult to obtain gluten-free products with the same properties without gluten. Therefore, both improving the technological properties and increasing nutritional value have been gained importance. Alternative protein sources play an important role for the formation of the desired dough structure and improvement of quality characteristics like color, appearance, texture and flavor after baking. Viscoelasticity, nutrient content, dough firmness and color-taste-fragrance acceptability of gluten-free products have been studied by several researchers. The most commonly used gluten alternatives are milk proteins, egg albumin and vegetable proteins. Recently, algae and edible insects, which contain high protein as well as high amounts of bioactive compounds, have been used as an alternative to gluten. In this review, it is aimed to give information about protein alternatives to gluten and their contributions to the nutritional value and technological properties of gluten-free products.
\end{abstract}

Keywords: Celiac disease, Protein substitutes, Gluten-free bakery products

\footnotetext{
* Sorumlu Yazar: sevgiyagdi@stu.aydin.edu.tr
} 


\section{Giriş}

Çölyak hastalığı dünya nüfusunun \%1-2'sini etkileyen en yaygın gıda intoleranslarından biridir. Çölyak hastalığ 1 bağırsaklarda sindirime katkı sağlayan villusların yapılarında bozulmaya neden olarak besinlerin emilimini engellemekte ve ince bağırsakta tahribata neden olmaktadır. Bu hastalığa sahip kişilerin, başta buğday olmak üzere çavdar, arpa ve bazı yulaf çeşitlerini tüketmeleri durumunda sağlık sorunları ortaya çıkmaktadır. Bu etkilerin önlenmesi ve/veya azaltılmasında en etkili yöntem glutenin diyetten çıkarılmasıdır. Glutensiz diyet, çölyak hastalarının yanı sıra, son yıllarda bireysel tüketim tercihleri ve popüler diyetler sebebiyle diğer tüketici grupları tarafından da ilgi görmektedir (Mutlu ve ark., 2019).

Fırıncılık ürünlerinin görünüşü, iç yapısı, pişme ve reolojik özelliklerinde gluten önemli bir rol oynamaktadır. Gluten, gliadin ve glutenin fraksiyonlarından oluşan bir depo proteinidir. Gliadin fraksiyonu 28.000-55.000 molekül ağırlığına sahip, hamura uzayabilirlik ve viskozite sağlarken, glutenin fraksiyonu ise elastikiyet ve yapışkanlıktan sorumludur (Hayıt ve Gül, 2017). Hamurun yapışkan olması ve viskoelastik özelliklerinin yanı sıra gluten fermentasyon süresince karbondioksit gazının tutulmasını sağlayarak ekmeklerin kabarmasına ve gözenekli yapı oluşmasına yardımcı olur. Glutenin uzaklaştırılması ile cıvık bir hamur elde edilmekte, pişmiş üründe ufalanan bir tekstür gözlenmekte ve pişirmeden sonraki dönemde kalite kayıpları oluşmaktadır (İşleroğlu ve ark., 2009). Bu problemler göz önüne alındığında, glutensiz ürün formülasyonlarına farklı protein kaynaklarının ilave edilmesi zorunluluğu ortaya çıkmaktadır. Glutene alternatif birçok hayvansal (peynir altı suyu, yumurta beyazı, kollajen) ve bitkisel (soya, bezelye, barbunya, ayçekirdeği, kanola, patates, mısır, pirinç) protein kaynağının kullanılması ile hem protein içeriğini arttırmak hem de ürüne fonksiyonel özellikler kazandırmak mümkün olmaktadır (Rai ve ark., 2018). Son yıllarda alg ve yenilebilir böceklerin de yüksek protein içerikleri ve biyoaktif bileşenler açısından zengin olmaları dolayısıyla gıda uygulamalarında kullanımları hız kazanmıştır (Skendi ve ark., 2021).

Teknolojik problemlere ilave olarak, glutensiz diyet uygulayan kişilerde beslenme yetersizlikleri özellikle vitamin ve mineral eksiklikleri görülmektedir (Rico ve ark., 2019). Aynı zamanda, glutensiz ürünlerde karbonhidrat ve yağ içeriğinin fazla, protein ve diyet lif oranının ise az olduğu bildirilmektedir (Yıldırım, 2020). Tüm bu olumsuzluklara ek olarak, glutensiz ürünlerin daha pahalı olması ve ürün çeşitliliğinin az olması gibi durumlar da söz konusudur. Glutensiz ürünlerin üretiminde hem teknolojik hem de besin değerleri açısından uygun maliyetlerle ürün üretilmesi konusunda yapılan çalışmalar son yıllarda hız kazanmıştır. Bu derlemeyle birlikte glutene alternatif olabilecek protein kaynaklarının; glutensiz firıncılık ürünlerinin protein içeriğine ve kalitesine olan etkisinin incelenmesi amaçlanmıştır.

\section{Glutensiz Ürünlerde Kullanılan Protein Kaynakları}

Glutensiz ürünlerin üretiminde gluten eksikliğinden dolayı meydana gelen teknolojik ve besinsel kayıpların önlenmesi için farklı protein kaynakları kullanılabilmektedir. Ancak glutenin firıncılık ürünlerinde önemli bir yere sahip olmasından dolayı, diğer protein kaynakları ile ikame edilmesi ve aynı teknolojik özelliklerde ürün üretilmesi oldukça güçtür. Son yıllarda bu konuda yapılan çalışmalar hız kazanmış ve farklı protein kaynaklarının kullanımı ile gluten içeren ürünlere eş ürünler üretilmeye başlanmıştır. Ayrıca firıncılık ürünlerinde istenen bir reaksiyon olan Maillard reaksiyonlarının gelişmesi, tat ve aromanın iyileştirilmesi için proteine ihtiyaç duyulmaktadır (Deora ve ark., 2015). Gluten proteininin varlığının bir diğer katkısı da bayatlamayı geciktirmesidir. $\mathrm{Bu}$ yüzden glutensiz ürünlerin raf ömrünün uzatılması için alternatif ve zengin içerikli bir protein kaynağına ihtiyaç duyulmaktadır (Özuğur ve Hayta., 2011).

Kullanılan protein kaynağına bağlı olarak glutensiz ürünlerin hem teknolojik hem de reolojik özellikleri farklılık göstermektedir (Matos ve ark., 2014). Glutene alternatif olarak hayvansal ve bitkisel kaynaklı proteinlerin yanı sıra algler ve yenilebilir böcekler de glutensiz ürünlerde protein içeriğini ve kalitesini yükseltmek amacıyla kullanılmaya başlanmıştır (Tablo 1). Farklı kaynaklardan elde edilen bu proteinler glutensiz gidalara üç farklı formda katılabilmektedir ve protein konsantrasyonuna bağlı olarak protein unları (\%10-20), protein konsantreleri (\%55-60) ve protein izolatları (\%80) olarak kategorize edilmektedir (Skendi ve ark., 2021). Bitkisel kaynaklardan elde edilen proteinlerin amino asit kompozisyonu hayvansal kaynaklardan elde edilenlere kıyasla daha az miktarda metiyonin ve lizin esansiyel aminoasitlerini içermektedir. $\mathrm{Bu}$ sebeple farklı protein kaynaklarının kombine edilerek kullanılması protein kalitesini arttırmaktadır.

\subsection{Hayvansal Protein Kaynakları}

Hayvansal kaynaklı proteinler arasında süt ve yumurta proteinleri glutensiz ürünlerde protein miktarını arttırmak ve amino asit kompozisyonunu iyileştirmek amacıyla en fazla kullanılan protein kaynaklarıdır. Ayrıca peynir endüstrisinde yan ürün olarak elde edilen peynir altı suyu (whey) da glutensiz ürünlerde sıklıkla kullanılmaktadır. Hayvansal proteinler, iyi çözünebilmeleri, sıkı emülsiyon oluşturmaları, köpük yapma kapasitelerinin iyi olması ve yüksek stabiliteleri sebebiyle teknolojik açıdan da pek çok fayda sağlamaktadır (Skendi ve ark., 2021).

Süt kaynaklarından elde edilen proteinlerin kullanılması ile glutensiz firıncılık ürünlerinde, dokunun ve rengin iyileştirilmesinin yanı sıra bayatlamayı da geciktirilebilmektedir (Arendt \& Dal Bello, 2008). Glutensiz ürünlerin süt proteinleri ile zenginleştirilmesi teknolojik faydalarına ilave olarak kalsiyum ve lizin, metiyonin ve triptofan gibi e sansiyel amino asitler açısından da zenginleştirilmiş olur (Krupa-Kozak ve ark., 2013). Glutensiz formülasyonlarda en yaygın olarak çalışılan süt proteinleri; kazein ve peynir alt1 suyu proteinleridir. Kazein peynire viskoelastik ve ağsı yapı kazandıran bir proteindir aynı zamanda iyi bir kıvam arttırıcı ve bağlayıcıdır. Bu özelliği sebebiyle kazein, hamuru stabilize eder, esnek ve elastik bir görünüm verir. Peynir altı suyu konsantresi ve izolatı glutensiz ürünlerde jelleşmeyi sağlayarak kıvama katkıda bulunur (Büyükbeşe ve ark., 2020). Ancak, süt proteinlerinin kullanımı ile ilgili bazı kısıtlamalar mevcuttur. Gluten intoleransı veya çölyak hastalığı sebebiyle bağırsak emilimi bozulan kişilerde süt proteinlerinin kullanılması ile laktoz intoleransının da gelişme riski söz konusudur (Deora ve ark., 2015). Ayrıca bir çalışmada glutensiz makarnaya peynir altı suyu proteini eklenmesi ile örneklerin parlaklık ( $\left.\mathrm{L}^{*}\right)$ değerinde düşme gözlenmiştir (Dedeoğlu, 2020). Bu sebeple, yüksek proteinli ve düşük laktoz içerikli hayvansal protein kaynaklarının (sodyum kazeinat, süt proteini izolatı gibi) kullanımı ile daha kabul edilebilir ürün şekli, 
geliştirilmiş bir hacim ve daha sıkı dokuya sahip ürünler üretilmesinin yanı sıra laktoz intoleransı oluşma riskinin de ortadan kaldırılması söz konusudur (Gallagher ve ark., 2004).

Son y1llarda, yumurta proteinleri kaliteli bir protein kaynağı olması ve hamura kolaylıkla dahil edilebilmeleri nedeniyle glutensiz ürünlerin üretiminde yaygın olarak kullanılmaktadır. Özellikle fırıncılık ürünlerinin üretiminde glutenin sağladığı hacim artışını ve esnek ağsı yapıyı glutensiz ürünlerde sağlayabilmesi dolayısıyla önemli bir protein ikamesi konumundadır (Deora ve ark., 2015). Glutensiz pirinç makarnasına \%7,5 oranında ilave edilen kurutulmuş yumurta proteinleri ile (beyazı, sarısı, tamamı) son ürünün çiğnenebilirlik, sertlik ve viskoelastik özelliklerinde iyileşme görülmüştür (Witek ve ark., 2020). Marti ve ark. (2014)'ın yaptığı bir çalışmada ise yumurta albüminiyle zenginleştirilmiş glutensiz makarnada albümin ikamesiyle daha homojen bir protein ağı oluşumu ve makarnanın dokusal-yapısal özelliklerinde iyileşme bulunmuştur. Bu çalışmada aynı zamanda yumurta akı ikamesi; peynir altı suyu proteinleri kullanılarak yapılan glutensiz makarnaya kıyasla daha az pişme kaybının yanı sıra daha sıkı bir yapıya sahip olduğu ve daha besleyici olduğu rapor edilmiştir. Hem glutensiz hem de yumurta içermeyen kek üretimi ile ilgili bir çalışmada ise, glutensiz keklerin dokusunu ve görünümünü iyileştirmek için mısır nişastası ve guar zamkı ile birlikte soya protein izolatı kullanılmıştır (Tambunan ve ark., 2015). Shevkani ve Singh (2014) ise; gaz oluşumunu ve glutensiz keklerinin elastikiyetini iyileştirmek için barbunya, bezelye ve amarant protein izolatları kullanmıştır. Çalışmaların geneline bakıldığında, en iyi sonuçlar yumurta proteininin transglutaminaz ile birlikte kullanıldığ örneklerde ortaya çıkmıştır. Bu şekilde hamurda daha uygun bir ağ görünümü sağlanmıştır (Storck ve ark., 2013). Kullanılan protein kaynağına göre üretilen glutensiz ürünlerin yapısal özelliklerinin ve besin değerlerinin değiştiği görülmektedir. Matos ve ark. (2014)'ın yaptığı bir çalışmada farklı protein kaynaklarının (kazein, bezelye proteini izolatı, soya proteini izolat1, yumurta beyazı proteini) glutensiz keklerin reolojik ve kalite özelliklerine etkisi incelenmiştir. Kazein ve yumurta beyazı proteinlerinin glutensiz keklerde hacim artışını sağladığı ve hem reolojik hem de teknolojik özelliklerin kullanılan proteinin kaynağına göre farklılık gösterdiğini rapor etmişlerdir.

\subsection{Bitkisel Protein Kaynakları}

Tahıllar, psödotahıllar, baklagiller ve yağlı tohumlar glutensiz ürünlerin üretiminde sıklıkla kullanılmaktadır. Kolay bulunabilmeleri, ucuz olmaları, yüksek miktarda protein içermelerinin yanı sıra katıldıkları ürünlere fonksiyonel özellikler kazandırmaktadırlar. Hayvansal kaynaklı proteinlerin alerjenik karakterde olmaları sebebiyle bitkisel kaynaklı proteinlere olan ilgi gün geçtikçe artmaktadır (Skendi ve ark., 2021). Ekstraksiyon, çöktürme, ultrafiltrasyon gibi işlemler ile bitkilerden proteinler izole edilmekte ve glutensiz ürünlerin üretiminde kullanılmaktadır (Yavuz ve Özçelik, 2016). Glutensiz fırıncılık ürünlerinde protein kaynağı olarak kullanılan pirinç kepeği protein konsantresinin hamur elastikiyetini ve mukavemetini geliştirdiği, nohut ve mercimek unu ilavesinin protein ve diyet lifi oranında anlamlı bir gelişme sağladığı, pisilyum tozu ikamesinin yoğurma sırasında hamurun kıvamını arttırdığı, fermente teff unu eklenmesinin kırıntı sertliğini azalttığını, kinoa unu dahil edildiğinde yine hamur yapısı ve lif içeriğine katkısı olduğu, karabuğday ununun ise pişirme özelliklerini iyileştirdiği yapılan çalışmalar ile kanıtlanmıştır (Naqash ve ark., 2017).
Tahıl proteinleri aminoasit dizilimi bakımından oldukça zengin içeriğe sahiptir ve birçok çalışmada glutensiz ürünlerde tahıl proteinlerinden (mısır, yulaf, pirinç) özellikle zenginleştirme açısından yararlanılmaktadır. Baklagiller tahıllara oranla daha fazla protein içermektedirler, ancak tahıl üretimi daha yaygın olduğu için hammadde ulaşımı açısından protein tercihi olarak ilk sıralarda yer almaktadırlar. Glutensiz ürünler ile ilgili yapılmış çalışmalarda, pirinç ve mısır unu çok sıklıkla buğday unu yerine kullanılmıştır. Pirinç ununun alerjen etkisinin düşük olması ve buğdaya oranla daha yüksek lizin içeriğine sahip olması sebebiyle tercih edilmektedir (Ergin, 2011). Pirinç kepeği ve \%2 oranında albümin katkılı glutensiz ekmeklerde, diyet lifi içeriği ve protein değeri, pirinç kepeğindeki çözünür ve çözünmeyen diyet lifi içeriğine doğrudan bağlı olmasına dayanarak, pirinç kepeğinin katkısıyla protein değerlerinin yanı sıra nihai ekmeğin renginin ve hacminin de arttı̆̆ Özellikle kahverengi pirinç besin içeriğinin yüksek olması ve gluten içermemesi sebebiyle glutensiz ürünlerin üretiminde kullanılmaya başlanmıştır.

Baklagiller bitkisel protein kaynağı olarak oldukça önemli bir yere sahiptir. Ayrıca, baklagiller diyet posası, sindirilemeyen nişasta, vitamin ve mineral içeriği açısından da oldukça iyi bir kaynaktır (Türksoy, 2018). Özellikle bezelye, mercimek, soya ve nohut unu protein içeriği bakımından zengin olduğu için çoğunlukla tercih edilmektedir. Glutensiz ürünlerde kullanılan tahıllar lizin amino asidi açısından yetersiz kalırken, baklagil unu ilavesiyle ürünün besin içeriği arttırılmakta ve esansiyel aminoasit oranında da artış sağlanmaktadır (Marco ve Rosell, 2008). Esansiyel aminoasitler açısından ürünü zenginleştirmek adına çeşitli çalışmalarda ilave protein kaynağı olarak chia tohumu kullanımı ile özellikle metiyonin ve sistein amino asitlerini dengeli bir şekilde içeren ürünler üretmek mümkün olmaktadır (Menga ve ark., 2017).

Bezelye üretimi ve işlenmesi kolay bir baklagil olmasının yanı sira, aminoasit kompozisyonu bakımından gida endüstrisinde fonksiyonel bir baklagil olarak kullanılmaktadır (Çetiner ve Bilek, 2018). Nohut ise kıvam arttırıcı ve emülgatör özelliği sebebiyle glutensiz ürünlerde protein ikamesi olarak kullanılmaktadır. Mercimek proteini flavonoidler ve protein içeriği açısından zengin; sindirilebilirliği yüksek bir bakliyattır. Gimènez ve ark. (2013)'nın, bakla unu (\%30) ve mısır unu (\%70) kullanarak ürettikleri glutensiz spagettilere özellikle diyet lifi açısından zengin olan bakla unu ilavesinin ürünün protein içeriğini arttırmanın yanı sıra diyet posasını, tekstürel özelliklerini ve fizikokimyasal kalitesini de anlamlı oranda geliştirdiğini vurgulamışlardır.

Soya proteini glutensiz ürünlerde gevrekliği, hamurun yapısını ve esnekliğini geliştirmektedir (Aydar ve ark., 2019). Ancak, soya proteini ilave edilen glutensiz ürünlerde hacim artışı yetersiz kalmaktadır (Ziobro ve ark., 2013). Glutensiz ekmek formülasyonuna patates ve soya proteini ilavesi, diğer proteinlere kıyasla daha yoğun bir kırıntı yapısına sahip daha küçük ekmekler elde edilmesini sağlamıştır. Bununla birlikte, keçiboynuzu, acı bakla ve bezelye ilavesi, daha büyük hücre gözenekleri ve daha yumuşak bir ekmek kırıntısı ve artan bir hacim ile sonuçlanmıştır. Verilerin analizine bakıldığında ürüne eklenen proteinin özellikleri ekmeğin özelliklerinin oluşmasına öncülük etmiştir. Köpürme işlevlerinin ve hamurdaki proteinlerin çözünürlüğünün, hamur özellikleriyle önemli ölçüde ilişkili olduğu görülmüş ve bu da nihai ekmek kalitesini etkilemiştir (Horstmann ve ark., 2017). Glütensiz (pirinç ve yumurta albümini bazlı) makarnaya tatlı patates, soya fasulyesi ve her ikisinin kombinasyonu ilave edilmiş 
ve sonuçta sadece soya fasulyesi ilave edilen örneklerde pişme süresi kısalmış, proteinler arası daha güçlü bir ağ oluşumu gözlenmiştir (Marengo ve ark., 2018). Bu gibi çalışmalar sayesinde glutensiz ekmek formülasyonlarına bitkisel protein ilave edilmesinin nihai ürüne olan etkisinin tahmin edilmesi sağlanmaktadır. $\mathrm{Bu}$ da, hem glutensiz ekmek kalitesinin iyileştirilmesine yardımcı olmakta hem de besin değerini arttırmaktadır.

Tahılımsı veya yalanc1 tahıl olarak da adlandırılan, psödotahıllar mineral, vitamin, esansiyel amino asitler ve yă asitleri bileşimleri açısından oldukça zengin olmaları, gluten içermemeleri sebebiyle nişasta veya pirinç bazlı ve düşük besin içeriğine sahip glutensiz ürünlere sağlıklı bir alternatif olarak kullanılmaktadırlar (Baykut, 2021). Karabuğday, yüksek protein (\%13) içeriği, nişasta (çoğunluğu dirençli nişasta), çözünür diyet lifleri, esansiyel aminoasit bileşimi (özellikle yüksek lizin içeriği), vitaminler, mineraller ve antioksidan maddeler gibi birçok değerli bileşenleri barındıran zengin bir besin kaynağıdır (Baykut, 2021). İçeriğinde yüksek oranda linoleik asit gibi çoklu doymamış yağ asitleri de bulunmaktadır (Aydar ve ark., 2019). Karabuğdayın protein açısından biyolojik değeri, yumurta proteinin biyolojik değerinin yaklaşı \%93'üne karşılık gelmektedir (Yaver ve Bilgiçli, 2020). Karabuğday (13,9 g/100 $\mathrm{g})$; glutensiz ürün endüstrisinde sıklıkla kullanılan mısır $(8,3$ $\mathrm{g} / 100 \mathrm{~g})$ ve pirinç $(6,9 \mathrm{~g} / 100 \mathrm{~g})$ ununa kıyasla çok daha yüksek oranda protein içermektedir.

Karabuğdayın nişasta fraksiyonu ve tane boyutu nedeniyle yüksek su absorplama kapasitesine sahiptir ve ayrica pirinç (1,5 $\mathrm{g} / 100 \mathrm{~g})$ ve misırla $(2,8 \mathrm{~g} / 100 \mathrm{~g})$ kıyaslandığında toplam diyet lifi içeriği de yüksektir $(9,2 \mathrm{~g} / 100 \mathrm{~g})$. Bu sayede eklendiği ürünün glisemik indeksini düşürüp ürünü daha sağlıklı hale getirmektedir. Bu da karabuğday ununun diğer glutensiz unlarla (mısır ve pirinç) karıştırılarak glütensiz ürün üretiminde başarıyla kullanılabileceğini gösterilmektedir (De Arcangelis ve ark., 2020). Başka bir çalışmada karabuğday unu farklı oranlarda $(\% 10, \% 20, \% 30, \% 40)$ glutensiz ekmek formüllerine eklenmiş eklenme yüzdesi arttıkça ekmek hacminde ve duyusal özelliklerinde iyileşmeler görülmüş. Ayrıca \%40’lık karabuğday ikameli ürünün bakır ve manganez içeriği diğerlerinde kıyasla yüksek bulunmuştur (Krupa-Kozak ve ark., 2013).

Amarant; tahıl, sebze ve baklagiller ile kıyaslandığında daha yüksek protein (\%13-14) içeriğine sahip olması ile birlikte vitamin, mineral ve biyoaktif bileşenler açısından da zengindir. $\mathrm{Bu}$ sebeple glutensiz ürünlerin üretiminde sıklıkla kullanılmaktadır (Mlakar ve ark., 2009). Cabrera-Chávez ve ark., (2012) yapmış oldukları bir çalışmada, glutensiz pirinç bazlı makarnanın dokusal özelliklerini iyileştirmek ve protein açısından zenginleştirmek için yeni bir ekstrüzyonla pişirme yöntemi kullanılmış ve amarant ilave edilerek mineral, lif içeriğinin yanında protein sindirilebilirliğinin de arttığını rapor etmişlerdir. Makarna yapımından önce 3:1 oranda pirinç unu ve amaranth karışımının ekstrüzyonla pişirilmesi, son ürünün tekstürel özellikleri açısından en iyi sonuçları vermiştir (CabreraChávez ve ark., 2012). Schoenlechner ve ark., (2010) yaptığı bir çalışmada ise amaranth, kinoa ve karabuğday unlarıyla üretilen glutensiz makarnada en az pişme kaybı ve en iyi doku sıklığı amarant ilave edilen örneklerde saptanmıştır.

Zengin aminoasit örüntüsüne sahip kinoa glutensiz ürün formülasyonlarında kullanıldığında hem besin değerlerinde artış hem de teknolojik özelliklerinde iyileşme sağlamaktadır (Caperuto, 2001). Pirinç ve misır unu kullanılarak yapılan glutensiz ekmeklerde, pirinç ve mısır unu yerine beyaz kinoa unu kullanımı ile hamurun gaz tutma kapasitesinde, tadında ve özgül hacminde belirgin bir artış elde edildiği görülmüştür (Elgeti ve ark., 2014). Kinoanın gıda endüstrisindeki bir diğer katkısı ise iyi bir emülsifiye aracı olması ve su tutma kapasitesinin yüksek olması sebebiyle glutensiz ürünlerde kıvam arttırıcı olarak da kullanılabilmesidir. $\mathrm{Bu}$ şekilde formüle edilmiş ürünlerde çok daha kaliteli duyusal özellikler tespit edilmiştir (Dağ ve Özkan, 2019). Hayıt ve Gül (2019)'un yaptığı çalışmanın duyusal analiz raporuna göre; kinoa unu ilave edilen ve kısmi pişir-dondur prosedürü uygulanan glutensiz ekmeklerin panelistler tarafindan kabul edilebilirliği artmıştır. Ayrıca Alencar ve ark. (2015)'nın yaptığı çalışmada glutensiz ekmek üretirken formülasyona kinoa ve amaranth unu ilave etmenin ürünün protein ve yağ içeriğine ek olarak nütrisyonel kalitesinin artmasını sağladığı bulunmuştur.

Yağlı tohumlar yüksek protein içermeleri sebebiyle glutensiz ürünlerin zenginleştirilmesinde kullanılmaktadır. Özellikle yüksek protein içerikleri sebebiyle pamuk tohumu (\%55-60 protein), yer fistığı (\%47-55 protein), susam (\%50 protein), keten tohumu (\%18-25 protein), çiya tohumu (\%19-23 protein) bu amaçla sıklıkla kullanılmaktadır (Çetiner ve Bilek 2018). Yağlı tohumların kullanımını kısıtlayan en önemli faktör, besin değeri olmayan bileşenler (fitik asit, okzalat, tripsin ve amilaz inhibitörleri) içermesidir. Örneğin keten tohumu \%3,36, kanola tohumu \%2,50 oranında fitik asit içermektedir (Berikten ve Kıvanç, 2018). Bu bileşenlerin çoğu protein çözünürlüğüne etki etmekte ve protein eldesini zorlaştırmaktadır. Özellikle fitik asitin sindirilebilmesi için gerekli olan fitaz enzimi insanlarda bulunmadığı için çözünemeyen kompleks yapılar oluşturup fizyolojik yararlınımları engellemesinin yanı sıra, oldukça güçlü bir şelatördür ve besin ögelerinin bağırsaktan absorbe olmalarını engelleyerek proteinlerin sindirilebilirliğini etkilemektedir (Şat ve Keleş, 2004). Bu gibi durumlarda, bazı ön işlemler ile (fermentasyon, çimlendirme, enzim uygulaması) besin değerlerini olumsuz etkileyen bu bileşikler uzaklaştırılabilmektedir (Çetiner ve Bilek, 2018). Özellikle baklagillerdeki fitik asit miktarını azaltabilmek adına çimlendirme yöntemi oldukça başarılı olarak kullanılmakta ve bu sayede gıda endüstrisine biyoyararlınımı yüksek ürünler kazandırılabilmektedir. Megat ve Azrina (2012)' nın yaptığı çalışmada, soya fasulyesi ve yer fistığının toplam fenolik, tanen ve fitik asit içerikleri üzerine çimlenmenin etkisini belirlenmiştir. Fitik asit içeriği çimlendirilmiş soya fasulyesinde önemli ölçüde azalmıştır. Fitik asit miktarındaki söz konusu azalma tohumlar çimlenirken ortaya çıkan enzimatik değişikliklerden kaynaklanmaktadır.

\subsection{Algler ve Yenilebilir Böcekler}

Algler, protein, yağ, vitamin, mineral, antioksidan ve doğal renk maddeleri açısından zengin birer kaynak olmalarından dolayı ürün zenginleştirme ve geliştirmede kullanılmaktadırlar. Özellikle glütensiz ürün üretiminde alglerin kullanılması Çölyak hastalarında görülen yetersiz mikro besin ögesi alımı sorununa alternatif bir çözüm olmaktadır. Różyło ve ark. (2017) yapmış oldukları bir çalışmada, kahverengi alg (Ascophyllum nodosum) ilave edilen glutensiz ekmeklerin fiziksel, duyusal ve antioksidan özellikleri incelenmiştir. \%4 oranında alg kullanılarak yapılan ekmeklerde daha büyük bir hacim elde edilmiştir. Artan kahverengi alg içeriği ile birlikte ekmek renginde ve dokuda da olumlu değişiklikler gözlemlenmiştir (Różyło ve ark., 2017.) Başka bir çalışmada ise Spirulina platensis ilave edilen glütensiz noodle örneklerinin protein içeriklerinin \%73'e kadar arttığı, 
vitamin, mineral ve aminoasit açısından zenginleştidiği rapor edilmiştir (Riyad ve ark., 2020).

Gıdaların algler ile zenginleştirilmesi çalışmalarında amino asit dizilimi ve protein içeriği bakımından farklı alg türleri (Algae Dunaliella, Green Algea, Laminaria ochroleuca, Spirulina spp.) kullanılmaktadır. Algler endüstride, maliyeti minimumda tutmak amacıyla izole edilmeden biyokütle olarak kullanılmaları sebebiyle ilave edildiği ürünlerde renk, aroma ve tekstür gibi duyusal özellikleri etkilemektedir (Skendi ve ark., 2021). Diprat ve ark. (2020) glütensiz ekmek üretiminde protein kaynağ Chlorella sorokiniana kullanımı ile ekmeklerde koyu yeşil bir renk ve düşük parlaklık rapor etmişlerdir. Ayrıca Chlorella sorokiniana ilavesi ile hacim ve tesktürde önemli bir değişim gözlenmemiştir. Khemiri ve ark. (2020), Nannochloropsis gaditana ve Chlamydomonas sp. ile zenginleştirilmiş glütensiz ekmek ürünlerinde protein, omega-3 yağ asitleri ve kül içeriğinin kontrol örneklerine kıyasla daha yüksek olmasına karşın yoğun bir yeşil-sarı renk oluşumu rapor etmişlerdir.

Artan dünya nüfusu ile birlikte sürdürülebilir gidaya olan ilgi de gün geçtikçe artmaktadır. Gıda endüstrisinde kullanılan protein kaynakları göz önüne alındığında hammadde yetersizlikleri ortaya çıkmakta ve sürdürülebilir alternatif protein kaynaklarına yönelim artmaktadır. Özellikle son yıllarda protein açısından zengin (\%20-76 protein) (Yilmaz, 2019) ve çiftlik hayvanlarına göre daha az atık üretme konularında dikkat çekici olan yenilebilir böcekler (sinekler, kınkanatlılar, tırtıllar, karıncalar, kriketler, çekirgeler) ilgi çekici hale gelmiştir (Aydın ve ark., 2021). Günümüzde halihazırda 1600 civarında böcek türü insanlar tarafından tüketilmektedir (Çabuk, 2021).
Kriket tozu, yüksek su ve yağ tutma kapasitesi ve insan tüketimine uygun mikrobiyolojik özelliklere sahip olması dolayısıyla glütensiz fonksiyonel gıdaların üretimi için umut vadeden önemli bir kaynaktır. Da Rosa Machado ve Thys, (2019)'in yaptığı bir çalışmada, mercimek ve karabuğday unlarının kullanımına kıyasla glütensiz ekmekler için Kriket (Gryllus assimilis) tozunun kullanımı ile kabul edilebilir teknolojik özelliklere ve yüksek protein içeriğine sahip glütensiz ekmek üretmişlerdir. Kowalczewski ve ark. (2021)'ın yaptığı bir çalışmada ise, kriket tozu (Acheta domesticus) ilave edilen örneklerin daha geç bayatladığı ve ekmek sertliğinin daha az olduğu rapor edilmiştir. Bu durum ise ilave edilen kriket tozunun moleküler seviyede bir değişime sebep olarak su transferini stabilize etmesi ile açıklanabilmektedir. Protein kaynağı olarak mercimek ve karabuğday unu yerine kullanılan kriket unlarının daha stabil bir yapı oluşturmaları sebebiyle ekmek sertliğini arttırmıştır. Ayrıca, ekmeklerin yapışkanlık ve esneklik özelliklerini iyileştirmede kriket unlarının daha etkili olduğu görülmüştür. Yapışkanlığı yüksek olan ekmek, dilimleme ve çiğneme sırasında bütünlüğünü korurken esneklik özelliği iyi olan ekmekler ise sıkıştırılıp bırakıldıklarında eski haline geri dönebilme özelliğine sahiptir. Ancak, yüksek protein içeriği sebebiyle kriket unlarının kullanımı ile ekmek iç yapısı yüksek poroziteye sahiptir. Yapılan çalışmalarda, daha kaliteli ekmek üretimi için yüksek yağ içeriği sebebiyle kriket unu kullanılan ekmeklerde ilave yağ kullanılmaması gerektiğini rapor etmişlerdir (Skendi ve ark., 2021).

Tablo 1. Farklı protein kaynaklarının glutensiz ürünlerde kullanımı ve ürün kalitesine etkileri

\begin{tabular}{|c|c|c|c|}
\hline Protein Kaynağı & Glutensiz Ürün & Üründe meydana gelen değişim & Referanslar \\
\hline $\begin{array}{l}\text { Yumurta albümini ve peynir } \\
\text { alt1 suyu proteini }\end{array}$ & $\begin{array}{l}\text { Pirinç unu ile yapılmış } \\
\text { makarna }\end{array}$ & $\begin{array}{l}\text { Düşük pişirme kaybı ve makarna } \\
\text { görüntüsünde iyileşme görülmüş̧ür. }\end{array}$ & Marti ve ark., 2013 \\
\hline $\begin{array}{c}\text { Soya, bezelye protein izolat1, } \\
\text { yumurta beyazı proteinleri, } \\
\text { kazein }\end{array}$ & $\begin{array}{l}\text { Pirinç unu ile yapılmış } \\
\text { kek }\end{array}$ & $\begin{array}{l}\text { Kazein ve yumurta beyazı proteinleri kek } \\
\text { hacmini arttırmış, bezelye protein izolatı daha } \\
\text { yumuşak ve elastik bir yapı kazandırmıştır. }\end{array}$ & Matos ve ark., 2014 \\
\hline $\begin{array}{l}\text { Kazein ve albümin protein } \\
\text { izolatları }\end{array}$ & $\begin{array}{l}\text { Pirinç unu ile yapılmış } \\
\text { ekmek }\end{array}$ & $\begin{array}{l}\text { Kabuk tekstürü iyileştirilmiş ve daha iyi } \\
\text { spesifik hacim elde edilmiştir. }\end{array}$ & Storck ve ark., 2013 \\
\hline $\begin{array}{l}\text { Albumin, kollajen, bezelye, } \\
\text { acı bakla ve soya proteini }\end{array}$ & $\begin{array}{l}\text { Misır ve patates nişasta } \\
\text { ile yapılmış ekmek }\end{array}$ & $\begin{array}{l}\text { Soya proteini ve kollajen spesifik hacmi } \\
\text { azaltmış, acı bakla proteini ve albümin ise } \\
\text { arttırmıştır. }\end{array}$ & Ziobro ve ark., 2013 \\
\hline Yumurta proteini & $\begin{array}{l}\text { Pirinç unu ile yapılmış } \\
\text { makarna }\end{array}$ & $\begin{array}{c}\text { Makarnanın çiğnenebilirliğini ve sertliğini } \\
\text { arttırmıştır. }\end{array}$ & Witek ve ark., 2020 \\
\hline $\begin{array}{c}\text { Kahverengi alg } \\
\text { (Ascophyllum nodosum) }\end{array}$ & $\begin{array}{l}\text { Pirinç, mısır ve darı unu } \\
\text { ile yapılmış ekmek }\end{array}$ & $\begin{array}{l}\text { Ekmek hacmi artmış, sertlik azalmıştır. Kabuk } \\
\text { bayatlaması artan alg konsantrasyonu ile } \\
\text { azalmıştır. Ekmeğin antioksidan özellikleri } \\
\text { artmıştır. }\end{array}$ & Różyło ve ark., 2017 \\
\hline Spirulina platensis & $\begin{array}{l}\text { Patates unu ile yapılmış } \\
\text { noodle }\end{array}$ & $\begin{array}{l}\text { Hacimde, mineral, vitamin ve esansiyel amino } \\
\text { asit içeriğinde artış görülmüşsür. }\end{array}$ & Riyad ve ark., 2020 \\
\hline Kriket (Gryllus assimilis) & $\begin{array}{l}\text { Pirinç ve mısır unu ile } \\
\text { yapılmış ekmek }\end{array}$ & $\begin{array}{l}\text { Su ve yağ tutma kapasitesinde artış ve } \\
\text { gözenekli bir ekmek yapısı görülmüştür. }\end{array}$ & $\begin{array}{c}\text { Da Rosa Machado \& Thys } \\
2019\end{array}$ \\
\hline Kriket (Acheta domesticus) & $\begin{array}{l}\text { Misır ve patates nişastası } \\
\text { ile yapılmış ekmek }\end{array}$ & $\begin{array}{l}\text { Daha koyu bir kabuk rengi elde edilmiş, } \\
\text { gözenekli bir ekmek yapısı görülmüşsür. } \\
\text { Antioksidan aktivitesi artmıştır. }\end{array}$ & $\begin{array}{l}\text { Kowalczewski ve ark., } \\
2021\end{array}$ \\
\hline
\end{tabular}




\section{Sonuç}

Sonuç olarak, gluten proteinine alternatif olarak kullanılan farklı protein kaynakları ile yapılan çalışmaların umut vadetmesine karşın glutenin sağladığı hamur yapısına ve tekstürel özelliklere ulaşılamadığı görülmektedir. Hem ürünün kalitesini yükseltmek, hem de gluten proteininin sağladığı doku ve yapının devamlılığını sürdürebilmek için glutensiz firıncılık ürünlerinin üretiminde farklı protein kaynaklarının tek başlarına veya kombine halde denenmesi ile ilgili çalışmalarda hidrasyon yeteneği, proteinlerin ekstraksiyon prosesleri, viskozite ve su tutma kapasitelerinin optimize edilmesi gerekmektedir. Algler ve yenilebilir böcekler kullanılarak yapılan glutensiz ürünler ile ilgili literatürde yeterli çalışma bulunmamaktadır. Glutensiz ürünler hızlı bir şekilde bayatladıkları için taze ürünlere olan ihtiyaç da fazladır. Her geçen y1l artan glutensiz beslenme tercihi ve zorunluluğuna bakıldığında, tüketicinin ihtiyaçlarına ve taleplerine cevap verilebilmesi için bu konuda daha fazla çalışma yapılması gerekmektedir.

\section{Teşekkür}

$\mathrm{Bu}$ çalışma İstanbul Aydın Üniversitesi Bilimsel Araştırma Projeleri Komisyonunca kabul edilen 07.07.2021 tarihli 2021/9 no.lu proje kapsamında desteklenmiştir.

\section{Kaynakça}

Alencar, N. M. M., Steel, C. J., Alvim, I. D., de Morais, E. C., \& Bolini, H. M. A. (2015). Addition of quinoa and amaranth flour in gluten-free breads: Temporal profile and instrumental analysis. LWT-Food Science and Technology, 62(2), 1011-1018.

Arendt, E. K., \& Dal Bello, F. (2008). Functional cereal products for those with gluten intolerance. In Technology of functional cereal products, 446-475. https://doi.org/10.1533/9781845693886.2.446

Aydar Y., Akgün A. \& Dengiz İ.T. (2019). Glutensiz diyette kullanılan alternatif hammaddeler. Geleceğin dünyasında bilimsel ve mesleki çalışmalar, mühendislik ve doğa bilimleri. (Manisa Celal Bayar Üniversitesi, Gıda Mühendisliği Bölümü).

Aydın, M., Arslan Danacıoğlu, D. \& Türker, S. (2021). Gıda teknolojisinde yenilikçi yaklaşımlar. Helal ve Etik Araştırmalar Dergisi, 3 (1), 19-36. https://doi.org/ 10.51973/head.925628

Baykut, E. D. (2021). Bazı Tahıl Benzeri Ürünlerin Besin İçeriği ve Gıda Endüstrisinde Kullanımı. Avrupa Bilim ve Teknoloji Dergisi, (23), 89-98. https://doi.org/10.31590/ejosat.789955

Berikten, D., \& Kıvanç, M. (2018). Fitazlar: Çevreye Etkisi, Beslenme ve Biyoteknolojideki Önemi. Akademik Gıda, 16(1), 109-119.

Büyükbeşe, D., Emre, E. E., \& Kaya A. (2020). Farklı Oranlarda Gam, Protein ve Emülgatör Kullanımı ve Jelatinizasyonun Pirinç Makarnası Kalitesine Etkisi. Akademik Gida, 18 (1), 45-63. https://doi.org/10.24323/akademik-gida.730113

Cabrera-Chávez, F., de la Barca, A. M. C., Islas-Rubio, A. R., Marti, A., Marengo, M., Pagani, M. A., ... \& Iametti, S. (2012). Molecular rearrangements in extrusion processes for the production of amaranth-enriched, gluten-free rice pasta. $\quad L W T, \quad 47 \quad$ (2),

https://doi.org/10.1016/j.lwt.2012.01.040

421-426.

Caperuto, L. C., Amaya-Farfan, J., \& Camargo, C. R. O. (2001). Performance of quinoa (Chenopodium quinoa Willd) flour in the manufacture of gluten-free spaghetti. Journal of the Science of Food and Agriculture, 81 (1), 95101.

https://doi.org/10.1002/10970010(20010101)81:1<95::AI D-JSFA786>3.0.CO;2-T

Çabuk, B. Influence of grasshopper (Locusta Migratoria) and mealworm (Tenebrio Molitor) powders on the quality characteristics of protein rich muffins: nutritional, physicochemical, textural and sensory aspects. Food Measure $\quad 15, \quad 3862-3872 \quad$ (2021). https://doi.org/10.1007/s11694-021-00967-x

Çetiner, M., \& Bilek, S. E. (2018). Bitkisel protein kaynakları. Çukurova Tarlm ve Gida Bilimleri Dergisi, 33 (2), 111$126 . \quad$ https://dergipark.org.tr/en/ pub/cutarim/issue/42081/470649

da Rosa Machado, C., \& Thys, R. C. S. (2019). Cricket powder (Gryllus assimilis) as a new alternative protein source for gluten-free breads. Innovative Food Science \& Emerging Technologies, 56, 102180.

Dağ, Ş. R. O., \& Özkan, A. M. G. (2019). Kinoa (Chenopodium quinoa Willd.) üzerine bir derleme. Journal of Faculty of Pharmacy of Ankara University, 43(3), 309-333. https://doi.org/10.33483/jfpau.487757

De Arcangelis, E., Cuomo, F., Trivisonno, M. C., Marconi, E., \& Messia, M. C. (2020). Gelatinization and pasta making conditions for buckwheat gluten-free pasta. Journal of Cereal Science, 103073. https://doi.org/10.1016/j.jcs.2020.103073

Dedeoğlu, M. (2020). Glutensiz makarna üretim parametrelerinin optimizasyonu. (Yüksek lisans tezi, Karamanoğlu Mehmetbey Üniversitesi Fen Bilimleri Enstitüsü, Gıda Mühendisliği Anabilim Dalı) https://tez.yok.gov.tr/UlusalTezMerkezi/tezDetay.jsp?id= daz5c2EhfNMMW7EZuIMdJw\&no=QqvkNedQE_H-_8G8ide8g

Deora, N. S., Deswal, A. \& Mishra, H. N. (2015). Functionality of alternative protein in gluten-free product development. Food Science and Technology International, 21 (5), 364379. https://doi.org/10.1177/1082013214538984

Diprat, A. B., Thys, R. C. S., Rodrigues, E., \& Rech, R. (2020). Chlorella sorokiniana: A new alternative source of carotenoids and proteins for gluten-free bread. LWT, 134, 109974.

Elgeti, D., Nordlohne, S. D., Föste, M., Besl, M., Linden, M. H., Heinz, V., ... \& Becker, T. (2014). Volume and texture improvement of gluten-free bread using quinoa white flour. Journal of Cereal Science, 59 (1), 41-47. https://doi.org/10.1016/j.jcs.2013.10.010

Ergin, A. (2011). Çölyak hastalarına özel bisküvi, erişte ve pide üretimi (Yüksek lisans tezi, Pamukkale Üniversitesi Fen Bilimleri Enstitüsü). http://acikerisim.pau.edu.tr/xmlui/handle/11499/1407

Gallagher, E., Gormley, T. R., \& Arendt, E. K. (2004). Recent advances in the formulation of gluten-free cereal-based products. Trends in Food Science \& Technology, 15 (3-4), 143-152. https://doi.org/10.1016/j.tifs.2003.09.012

Giménez, M. A., González, R. J., Wagner, J., Torres, R., Lobo, M. O., \& Samman, N. C. (2013). Effect of extrusion conditions on physicochemical and sensorial properties of 
corn-broad beans (Vicia faba) spaghetti type pasta. Food chemistry, $136(2)$

538-545. https://doi.org/10.1016/j.foodchem.2012.08.068

Hayıt, F. \& Gül H. (2017). Çölyak ve çölyak hastaları için üretilen ekmeklerin kalite özellikleri. Journal of the Institute of Science and Technology, 7(1), 163-169.

Hayıt, F. \& Gül, H. (2019). Kinoa ununun ve kısmi pişirilerek dondurma yönteminin glutensiz ekmek kalitesi üzerine etkisi. Karadeniz Fen Bilimleri Dergisi 9 (2), 406-427. https://doi.org/10.31466/kfbd.647249

Horstmann, S. W., Foschia, M., \& Arendt, E. K. (2017). Correlation analysis of protein quality characteristics with gluten-free bread properties. Food \& function, 8 (7), 24652474. https://doi.org/10.1007/s00217-006-0405-y

İşleroğlu, H., Dirim, S. N., \& Ertekin, F. K. (2009). Gluten içermeyen, hububat esaslı alternatif ürün formülasyonları ve üretim teknolojileri. Glda, 34(1), 29-36.

Khemiri, S., Khelifi, N., Nunes, M. C., Ferreira, A., Gouveia, L., Smaali, I., \& Raymundo, A. (2020). Microalgae biomass as an additional ingredient of gluten-free bread: Dough rheology, texture quality and nutritional properties. Algal Research, 50, 101998. https://doi.org/10.1016/j.algal.2020.101998

Kowalczewski, P. Ł., Gumienna, M., Rybicka, I., Górna, B., Sarbak, P., Dziedzic, K., \& Kmiecik, D. (2021). Nutritional Value and Biological Activity of Gluten-Free Bread Enriched with Cricket Powder. Molecules, 26(4), 1184.

Krupa-Kozak, U., Bączek, N., \& Rosell, C. M. (2013). Application of dairy proteins as technological and nutritional improvers of calcium-supplemented gluten-free bread. Nutrients, 5 (11), 4503-4520. https://doi.org/10.3390/nu5114503

Marco, C., \& Rosell, C. M. (2008). Functional and rheological properties of protein enriched gluten free composite flours. Journal of Food Engineering, 88 (1), 94-103. https://doi.org/10.1016/j.jfoodeng.2008. 01.018

Marengo, M., Amoah, I., Carpen, A., Benedetti, S., Zanoletti, M., Buratti, S., ... \& Iametti, S. (2018). Enriching glutenfree rice pasta with soybean and sweet potato flours. Journal of food science and technology, 55(7), 2641-2648. https://doi.org/10.1007/s13197-018-3185-z

Marti, A., Barbiroli, A., Marengo, M., Fongaro, L., Iametti, S., \& Pagani, M. A. (2014). Structuring and texturing glutenfree pasta: egg albumen or whey proteins?. European Food Research and Technology, 238 (2), 217-224. https://doi.org/10.1007/s00217-013-2097-4

Matos, M. E., Sanz, T., \& Rosell, C. M. (2014). Establishing the function of proteins on the rheological and quality properties of rice based gluten free muffins. Food Hydrocolloids, 35, 150-158. https://doi.org/10.1016/j.foodhyd.2013.05.007

Megat Rusydi, M. R., \& Azrina, D. A. (2012). Effect of germination on total phenolic, tannin and phytic acid contents in soy bean and peanut. International Food Research Journal, 19(2).

Menga, V., Amato, M., Phillips, T. D., Angelino, D., Morreale, F., \& Fares, C. (2017). Gluten-free pasta incorporating chia (Salvia hispanica L.) as thickening agent: An approach to naturally improve the nutritional profile and the in vitro carbohydrate digestibility. Food Chemistry, 221, 19541961. https://doi.org/10.1016/j.foodchem.2016.11.151

Mlakar, S. G., Turinek, M., Jakop, M., Bavec, M., \& Bavec, F. (2009). Nutrition value and use of grain amaranth:
Potential future application in bread making. Agricultura, $6(4), 43-53$.

Mutlu, C., Tontul, S. A., Candal, C., \& Erbaş, M. (2019). Bazi tahil benzeri ürünlerin glutensiz kek üretiminde kullanimi. Gida, 44(5), 770-780.

Naqash, F., Gani, A., Gani, A., \& Masoodi, F. A. (2017). Gluten-free baking: Combating the challenges-A review. Trends in Food Science \& Technology, 66, 98-107. https://doi.org/10.1016/j.tifs.2017.06.004

Özuğur, G. \& Hayta, M. (2011). Tahıl esaslı glutensiz ürünlerin besinsel ve teknolojik özelliklerinin iyileştirilmesi. Gıda, $36 \quad$ (5), 287-294. https://dergipark.org.tr/en/pub/gida/issue/6914/92398

Phimolsiripol, Y., Mukprasirt, A., \& Schoenlechner, R. (2012). Quality improvement of rice-based gluten-free bread using different dietary fibre fractions of rice bran. Journal of Cereal Science, 56(2), 389-395. https://doi.org/10.1016/j.jcs.2012.06.001

Rai, S., Kaur, A., \& Chopra, C. S. (2018). Gluten-Free Products for Celiac Susceptible People. Frontiers In Nutrition, 5, 116. https://doi.org/10.3389/fnut.2018.00116

Rico, D., Ronda, F., Villanueva, M., Montero, C. P., \& MartinDiana, A. B. (2019). Development of healthy gluten-free crackers from white and brown tef (Eragrostis tef Zucc.) flours. Heliyon, 5(10), e02598. https://doi.org/10.1016/j.heliyon.2019.e02598

Riyad, Y. M., Naeem, M. M., \& Slama, S. Evaluation of glutenfree noodles fortified by Spirulina algae. https://doi.org/10.21608/enj.2020.144758

Różyło, R., Hameed Hassoon, W., Gawlik-Dziki, U., Siastała, M., \& Dziki, D. (2017). Study on the physical and antioxidant properties of gluten-free bread with brown algae. CyTA-Journal of Food, 15(2), 196-203. https://doi.org/10.1080/19476337. 2016.1236839

Schoenlechner, R., Drausinger, J., Ottenschlaeger, V., Jurackova, K., \& Berghofer, E. (2010). Functional properties of gluten-free pasta produced from amaranth, quinoa and buckwheat. Plant foods for human nutrition, 65 (4), 339-349. https://doi.org/10.1007/s11130-010-0194-0

Shevkani, K. \& Singh, N. (2014). Influence of kidney bean, field peaand amaranth protein isolates on the characteristics of starch-basedgluten-free muffins. International Journal of Food Science \& Technology, 49, 2237-2244.

Skendi, A., Papageorgiou, M., \& Varzakas, T. (2021). High Protein Substitutes for Gluten in Gluten-Free Bread. Foods, 10(9), 1997. $\quad$ https://doi.org/10.3390/ foods 10091997

Storck, C. R., da Rosa Zavareze, E., Gularte, M. A., Elias, M. C., Rosell, C. M., \& Dias, A. R. G. (2013). Protein enrichment and its effects on gluten-free bread characteristics. LWT-Food Science and Technology, 53 (1), 346-354. https://doi.org/10.1016/j.lwt.2013. 02.005

Şat, İ. G., \& Keleş, F. (2004). Fitik asit ve beslenmeye etkisi. Glda, 29(6), 405-409.

Tambunan, B.A., Julianti, E. \& Suhaidi, I. (2015). The making of gluten and egg free cake from composite flour of rice, cassava, potato starch, and soybean with the addition of hydrocolloid. Jurnal Rekayasa Pangan dan Pertanian, 3, 471-481.

Türksoy, S. (2018). Tam tane baklagil unlarının kimyasal, fonksiyonel ve reolojik özelliklerinin belirlenmesi. Glda, $43 \quad$ (1), 78-89. https://dergipark.org.tr/ en/pub/gida/issue/32293/334881 
Witek, M., Maciejaszek, I., \& Surówka, K. (2020). Impact of enrichment with egg constituents on water status in glutenfree rice pasta-nuclear magnetic resonance and thermogravimetric approach. Food Chemistry, 304, 125417.

Yaver, E. \& Bilgiçli, N. (2020). Tahıl benzeri ürünler: bileşimi, beslenme-sağllk üzerine etkileri ve tahıl ürünlerinde kullanımı. Food and Health, 6 (1), 41-56. https://doi.org/10.3153/FH20006

Yavuz, M., \& Özçelik, B. (2016). Bitkisel Protein İzolatlarının Fonksiyonel Özellikleri. Akademik Gıda, 14 (4), 424-430. https://dergipark.org.tr/en/ gida/issue/55781/763550
Yıldırım, E. (2020). Çölyak Hastalığı ve Glutensiz Besleme. Genel Sağllk Bilimleri Dergisi, 2 (3), 175-187. https://dergipark.org.tr/en/pub/jgehes/issue/ 58651/686873

Yilmaz, M. B. (2019). Farklı baklagil ve yenilebilir böcek unları ile zenginleştirilmiş eriștelerin kalite ve bazı besinsel özelliklerinin belirlenmesi (Master's thesis, Sosyal Bilimler Enstitüsü)

Ziobro, R., Witczak, T., Juszczak, L., \& Korus, J. (2013). Supplementation of gluten-free bread with non-gluten proteins. Effect on dough rheological properties and bread characteristic. Food Hydrocolloids, 32 (2), 213-220. https://doi.org/10.1016/j.foodhyd.2013.01.006 